\title{
MY015A Gene
}

National Cancer Institute

\section{Source}

National Cancer Institute. MYO15A Gene. NCI Thesaurus. Code C125572.

This gene plays a role in the structure of stereocilia. 